\title{
Quality of Research in Aesthetic Book Publications
}

\section{Md. Amin bin Abdul Rahman al-Jarumi, Nur Sarah binti Tajul Urus}

To Link this Article: http://dx.doi.org/10.6007/IJARBSS/v11-i12/11921 DOI:10.6007/IJARBSS/v11-i12/11921

Received: 08 October 2021, Revised: 11 November 2021, Accepted: 25 November 2021

Published Online: 16 December 2021

In-Text Citation: (Al-Jarumi \& Urus, 2021)

To Cite this Article: Al-Jarumi, M. A. bin A. R., \& Urus, N. S. binti T. (2021). Quality of Research in Aesthetic Book Publications. International Journal of Academic Research in Business and Social Sciences, 11(12), 19711979.

\section{Copyright: $\odot 2021$ The Author(s)}

Published by Human Resource Management Academic Research Society (www.hrmars.com)

This article is published under the Creative Commons Attribution (CC BY 4.0) license. Anyone may reproduce, distribute, translate and create derivative works of this article (for both commercial and non0-commercial purposes), subject to full attribution to the original publication and authors. The full terms of this license may be seen at: http://creativecommons.org/licences/by/4.0/legalcode

Vol. 11, No. 12, 2021, Pg. $1971-1979$

Full Terms \& Conditions of access and use can be found at http://hrmars.com/index.php/pages/detail/publication-ethics 


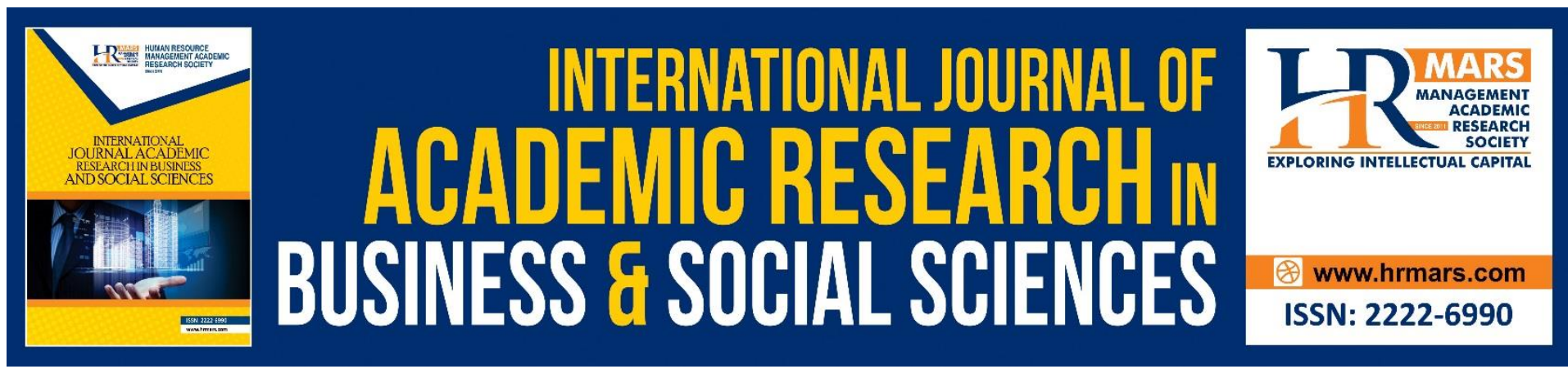

\title{
Quality of Research in Aesthetic Book Publications
}

\author{
Md. Amin bin Abdul Rahman al-Jarumi ${ }^{1}$ Nur Sarah binti Tajul \\ Urus $^{2}$ \\ ${ }^{1}$ Professor, Kulliyyah of Syariah and Law, Universiti Islam Antarabangsa Sultan Abdul Halim \\ Mu'adzam Shah (UniSHAMS), Malaysia, '²ecturer, Kulliyyah of Shariah and Laws, UniSHAMS. \\ Email: aminaljarumi@unishams.edu.my,nursarah@unishams.edu.my
}

\begin{abstract}
In order to produce an artistic work of books, then there need to be two main elements: First: Quality of research and Second: Quality of researchers. Even these combinations should move in teams. Otherwise, it is likely that good writing could not be produced. On the other hand, it should be noted that the researchers are something that was original 'without a soul', but it is moved by the people affectively (researcher). Of course, the people and community are detected by various problems and challenges, unlike the animals and plants. How will the noble efforts of people use 'research' to reach its goal? A researcher's life is like a little fishing boat weathering storms and waves to reach the 'island of hope' (producing a book of aesthetic value). So of course he needs the 'supplies' and 'self quality necessary so that he doesn't drift out of supplies in the middle of the ocean of his dreams. Hence, this paper will try to discuss what a researcher should prepare and do before beginning the journey in research while researching and completing research and ultimately publishing a quality book.
\end{abstract}

Keywords: Research, Supplies, Self-Quality.

\section{Introduction}

A technique of acquiring the quality of research in aesthetic work (book) publications is typically distinguished by a specific, creative, subjective, and case-by-case process. The authors see a similarity to design in social sciences and propose transferring the quality criteria of qualitative research to research-based design (Schöbel et al., 2021).

\section{Definitions}

\section{Quality of Scientific Research}

The behavior of a good person (the researcher) who is resolved to involve the efficacy of information, hypotheses, and assumptions or explain a viewpoint or phenomenon and

\footnotetext{
${ }^{1}$ Professor, Kulliyyah of Syariah and Law, Universiti Islam Antarabangsa Sultan Abdul Halim Mu'adzam Shah (UniSHAMS), Malaysia. aminaljarumi@unishams.edu.my

${ }^{2}$ Lecturer, Kulliyyah of Shariah and Laws, UniSHAMS. nursarah@unishams.edu.my
} 
understand the justifications and mechanisms of conducting it or establishing a successful outcome to a particular question or common habit that individuals and societies consider fundamental, (Hassan \& Willcocks, 2021).

\section{Quality Value of Manuscript (Books)}

Marquis de Voofnarg (a Western author) clarified his rationale as a 'clean and sacred essence' of a special mind and beautification of knowledge achieved by the intellect as a result of the 'harvest' of his long 'journey'. Some prominent academics believe that, despite an increase in the total number of article journal submissions, there has been little or no change in the quality of related publications. It is evident that an aesthetic book is of higher quality than an article paper, (Blau, 2019).

A quality book is an 'energy' of personal thinking growth and the development of reasoning charisma. The reader gathers knowledge from a book, then he will learn it and broaden it in his mind. Thus, the ideas he studies will result in thought and forms a chain of information and knowledge that carries the same idea and are added to it from his experiences and then digested to construct a new hope. Universities, on the other hand, are using sustainability to steer improvements to their campuses, curricula, governance, investments, procurement rules, and partnerships with their local communities. In short, sustainability is a foundation upon which particular techniques for guiding decision-making may be created, (Kibert et al., 2012).

A quality book is what composes its users to read it as well as quality education. It is of good quality in terms of its ideas and the subtitles of its content, its language style, and how it deals with the thoughts pointed out.

John Ruskin, an English thinker and commentator of the centuries during Queen Victoria, mentioned that "Life is short, the moment of silence is also a low point, so do not waste it by reading a book of no benefit. While books are valuable, they should be reachable to all human beings." (Werner et al., 1970).

Quality books contribute to quality readers. The relationship between the book and the reader is an effective process relationship that changes between both signals and statements. Thus, when a book devotes its meanings and contents to the reader's mind as the 'recipient', then the book holds the readers' notes and comments under it (الهوامش) which are illustrated by the information.

The new book does not at all prevent from opening up for new horizons readers and adding 'reconcivalence' and 'awareness' and contributing with experience and background that are constantly increasing and revealing to the readers' many new things about them each time the reader is quoted repeating his reading.

\section{Prerequisite for a Researcher}

To become a quality researcher, in producing a work (book) that has charm and aura (area), it is necessary to have two things to do: 
1. First: 'A lump of the brain' and its essence 'common sense'

That is 'prosperous intellect' (العقل السليم). This is crucial for the researchers to enable him to design, draft, explore, sketch titles and flick materials before writing begins. The prerequisite should be to bodies that are healthy based on the saying 'Arabic "العقل السليم في الجسم السليم" (A well-being common sense is found in prosperous anatomy).

\section{Second: 'A Piece of Heart' and its essence of 'feeling'}

That is a 'positive feeling' (الشعور الإيجابي) which is an intuition that brings together all the forces of 'spiritual' and 'intellectual-tual' to produce results that are 'ambitious', beautiful and early (estate). Perhaps writing doesn't have the 'estate' feature because the author has just a lump of the brain, but no piece of heart. Meaning, the writing fades (dull) because it is not infused with aesthetic values that are an attraction to the reader.

Thus, people who do not have a good sense and positive feelings cannot be authoritative researchers and authors. However, both matters are not gifted one, they can be sharpened, sharpened and sharpened, if the person who wants to engage is willing to make changes to his 'common sense' and 'feelings' (Covey, 1990).

\section{Steps To Take Before Starting Writing}

1. Possess academic qualification

Although there are people who do not have high academic qualifications who can become authors, usually the authors must possess high academic qualifications and sufficient valueadded such as a tendency to research and write. This is a credit to him, especially if the book he wants to write is an academic book that becomes the text or reference of a university student. Perhaps, academic qualifications are not required for books for general reading or 'casual reading'.

\section{Possess competency in writing}

Not everyone with academic qualifications is also competent in writing. I believe that a lecturer, for example, who holds a Master's Degree or Ph.D. to be a successful lecturer in producing academic writing should be competent in research. Competence is not a legacy or natural gift but requires long-term training. Perhaps starting with light-ups in newspapers, then in local magazines and later being born in book form.

\section{Possess specialization/expertise that he is proficient in:}

Specialization in the field of expertise is very important as attentive readers will look at the background of the author. His academic qualifications and the degrees he owns. For example, a person who is sincerely proficient in Syariah may not be an expert in the field of Usuluddin in addition to science and technology, even though he masters 'Arabic or English' which is a tool to understand the fields of knowledge.

This is in view of each individual there is a field he likes that allows him to reveal his thoughts and pour out his ideas in an orderly, robust, and effective way. The selection of this area of specialization is important because the information accumulated in the minds of the researchers is so abundant, the possibilities include also not the areas in which they are specializing. If not focused on the field of course, surely the analysis will be loose, there are loopholes that do not convince the reader. 
This means that a researcher shall master a field by al-'ilm al-rasikh /العلم الراسخ which is an in-depth knowledge of what to write, as stated by Allah SWT in the Qur'an, surah Ali 'Imran verse 7:

"والراسخون فى العلم يقولون أمنا به كل من عند ربنا وما يذكر إلا أولوا الألباب."

And instead of 'al-'ilm al-zahir/العلم الظاهر' which is horizontal knowledge that is not understood to the bottom as stated by Allah SWT on the Romans in surah al-Rum verse 7:

"يعلمون ظاهرا من الحياة الدنيا وهم عن الأخرة هم غافلون".

4. Looking for titles that have not yet spread among the masses and are not yet available in the book market:

Quality researchers should use available channels in searching for book titles that are not yet on the market or are not yet publicly known the details. Therefore, researchers. quality authors should first examine what previous researchers and authors have achieved before drawing up their writing.

This is because previous studies of imaginative and creative writers usually contained 'recommendations' or suggestions on the last sheet of their writing. Those are the points where the previous authors haven't broken it. Therefore, quality researchers can start writing them from these points.

The selection of titles is aimed at setting the issues to be discussed and discussed. Maybe it's a scientific issue that requires a solution. It starts from scientific assumptions through research, debate, and analysis to highlight scientific facts or facts related to questions and interpretations in solving the issues presented.

However, if the title to be written is already on the market, then it can be designed something new like 'a commentary' (النقد) or analysis and reviews 'analytical approach' (الشرح) from an untouched point of view and therefore new ideas can be highlighted without copying old ideas, let alone if done in the form of 'adaptation' and moreover plagiarism.

5. Like to open, disassemble and drill original sources (premier /al-masadir'asliyyah anon-secondary (secondary /al-masadir thanawiyyah المصادر الثانوية/) and centralize references to it:

It is acknowledged that sometimes it is difficult to get premier resources that speak inclusively and in-depth the title to be written. So it takes as many researchers to travel for a long time and to remote areas to find these resources.

Although in researching the old books or books (especially in the field of religion) which are named with 'Kutub al-Turath' or 'Mothers of scriptures' ('Ummahat al-Kutub) whose writing style (uslubnya) is quite difficult to understand, the information provided is first-handed. It is worth more than a reference to books translated or inseminated from these premier books. 
6. There needs to be academic trust in scientific sciences of knowledge (الأمانة العلميّة) It is a must in academic research. The scientific trust of something glued to a conscious soul and the right character (القلب الواعي) (الخلق المستقيم). There is a conscious taste of impurities and purity in implementing research accountability.

Hence, all citations made should be made to the original author. It is a noble sign of the heart of the researcher (كرامة الباحث). At this scientific trust, there is a conscious feeling about the authenticity and authenticity of the information to be served to the reader later, not the diffusion/citation/hook from the published book.

7. Possess a deep belief in self-sedation (كفاءة النفس) in conducting research A quality researcher should have deep styling (الإيمان العميق) his ability to research and design it in a form of exercised motion (العمل الدؤوب). Believing in self-empowerment means that the researcher believes that his research will produce a quality book. This research work should be considered a planned full-time move (full-time-maneuver) not a part-time and seasonal movement. The full focus of physical energy, 'aqliyyah and rohaniyyah should be focused on producing a quality book.

8. Not to look at others academically or underestimate their previous achievements:

There may be significant differences in grammar, content, and even the format of books written by previous authors. Perhaps their achievements correspond to the demands of the surrounding situation and atmosphere at the time the book was written. In a book published in the olden days, the possibility of finding its sources of reference is more difficult, if compared to the present. Especially if the references are abroad. Hence, it is not appropriate for a researcher to underestimate what the previous authors wrote.

\section{Has the value of 'Objectivity' in drawing up its Writing}

That is, adhering to knowledge and abstaining from personal-interest, hidden-agenda thoughts, similar to certain points of view and letting his 'habits', follows, and desires interfere in his research.

Instead, it shall be its intention and purpose to uphold rights and truths only. That is, he will not outline conclusions that are impossible to reach and instead sketch out the objectives that can be achieved by the person reading his book. This means that an authoritative researcher and author will let the reader of his own book make an 'assessment' of his thoughts that are emanated in his writings.

\section{When Starting A Writing}

\section{Manage Time and Patiently Face the Burden of Research}

A quality researcher should be able to manage his time management well to enable him to devise his work and be committed to the schedules that have been decided in his writing planning. Managing time is one of the most important traits for a quality researcher and author. This means that research should not be done 'whenever there is time', instead a researcher should schedule a specific time to research.

After going through the process of dismantling the sources of knowledge and information, a quality researcher can already recite the beautiful title of his research to be able to write a 
book that is dense, quality, and decorated with aesthetic characteristics as a result of what he has discovered by his intellect and heeded by his feelings.

He should be patient in the face of the burden of writing that may lead to 'depravity of thought' (al-habsah al-fikriyyah/الحبسة الفكرية) who will control the process of publishing his book. For example, al-Imam al-Shafi'i, for example, was given Allah SWT's intelligence to think, analyze and digest the problems of the law until finally successfully writing 'al-Risalah' which is the first book in Usul Fiqah, then followed by 'al-'um' and other books.

In this regard, al-Shaikh Muhammad Abu Zahrah stated that al-Shafi'i has never experienced 'depravity of thought' (الحبسة الفكرية)throughout his involvement in his writing and scientific movements. This may be referred to as his relationship with Allah SWT. He memorized the Qur'an and hadith as a child and the closeness of his relationship with his Tok Guru Imam Malik and the public.

\section{Winning 'Reality' from Merely 'Emotionally Arousing' in Writing}

Quality researchers and writers should solidify their taste for what is written. He should talk about the 'reality of something, which is something that the reader's tastes can feel, not an imaginary sketch that has no beginning and end. He doesn't need to look around for something that can evoke the reader's emotions in search of publicity and cheap reputation (cheap publicity and cheap refutation).

Sadly, there are many writers, especially writers of articles (in newspapers or electronic media for example) whose efforts are merely to evoke the emotions of readers. Naturally, they have their own goals to be famous and to reap cheap profits. That's not the hallmark of a successful book writer. A realistic and successful author is a writer who can provide the reader with added value to a knowledge that is already possessed and further corrects the reader's misconceptions about a fact and brighten his understanding of something vague.

\section{Have the Ability to Think and Make Assumptions/Assumptions}

It is a process of arousing ideas in thought. Perhaps delusions are a conduit for creating thoughts. However, the assumption is that the presence of thoughts is indiscriminately on solving problems without the need for obvious reasons.

The feeling comes as a 'reliever' on a person's thinking, whether in a relaxed state or between sleeping and care. It is a common phenomenon for someone who is using his mind. Therefore, it is necessary to record the ideas that came to the infants as soon as possible as it will stay away from one's thinking also in a fast and agile form. However, the ideas must be digested first as they are not among the channels (wasa'il) of scientific conviction. Maybe it's true or maybe it's the other way around.

\section{Master the Language used for Writing}

Language is a channel (wasilah) with which it can be completed the delivery of information and thoughts from one person to another person. In writing, this is not achievable except through the ability to master the grammatical methods used in writing. Although using the native language itself is easier than other languages, full mastery of the mother tongue 
requires the concept of 'al-itqan' (seriousness) or 'al-ahliyyah al-lughawiyyah' (mastery of the language) towards the language.

Since the practice in scholarly writing requires a smooth and educated style of language, it is inevitable that a writer master a foreign language to enable him to recite what is read in the language. Since English is the main language of knowledge, science, and technology today, it is necessary for writers to give priority to mastery of English.

Besides that, the Arabic language is the language of religious knowledge, so it should be fully mastered by the writers in the field of religion. However, it is more important for him to master both foreign languages as an added value to him.

\section{Use Standard and Clear Language}

A writer should use standard and clear language, away from less obvious words that the reader does not understand. If in the event he is forced to reveal scholarly and foreign terms, then it is necessary to elaborate. There is another way, which is to create an appendix of 'glossary' at the end of writing. For me, this is something that quality researchers and writers should not forget.

\section{Sincere to Research and Write with your Own Property (Money Cash), Hard Work, Time and Thought}

Research and writing is an effort that requires the sacrifice of money, time, and constant thinking ranging from searching for titles to the final point. It could take a year, two years or so. This is in contrast to the writing of an article for a magazine or journal.

It is believed that book writing is not very popular for academics in the university as the focus is more on writing in high-impact journals such as Scopus indexed journals. Perhaps the given scoring value system is higher than the score value of a book.

Whereas, in reality, the preparation of a book requires a longer period of time and the journey runs from the starting point of searching for research materials to the end of writing. In addition, the cost of publishing a book is more expensive than an article.

\section{After Finishing Writing}

1. Upon completion of the last draft of a book, before it is printed, it must be edited:

Editing can be done by the author himself if he is indirectly capable of editing the book. That means, maybe he's a veteran writer who has released a few books before where his edits are done on his own.

Otherwise, ask for help and views of others, including 'friends' and if possible made finalediting by experts in the written field as well as linguists. The objective is to get feedback on the positive and negative values found in the written book. This is to ensure that the book is of high-quality academic quality in terms of content, grammar, and technical format.

2. Finally, based on the feedback proposed by the valuers, all corrections, additions or reductions should be made, whether grammatically, content, or format as necessary. After that look for a well-known printing company and easily trade the book. 


\section{Conclusion}

The significance of writing was recorded in the first revelation of surah al-Alaq. Writing requires a great deal of trust and responsibility. Many academics are encouraged to write in order to share useful ideas and information. This is to realize the objective to build and grow a knowledge-savvy generation. A guide to living with fairness, integrity, honesty, and human dignity. This classic article presents a principle-centered approach for solving both personal and professional problems. With penetrating insights and practical anecdotes, this paper reveals a step-by-step pathway for living with respect and compassion.

\section{Acknowledgment}

This research received specific funding for ERA publication from UniSHAMS Research Cluster Serial Webinar 2021: 1 st and 2nd Series, on 22nd September and 13th October 2021 at UniSHAMS, Kuala Ketil, Baling, Kedah, Darul Aman, Malaysia.

\section{Corresponding Author}

Md. Amin bin Abdul Rahman Al-Jarumi

Professor, Kulliyyah of Syariah and Law, Universiti Islam Antarabangsa Sultan Abdul Halim Mu'adzam Shah (UniSHAMS), Malaysia.

Email: aminaljarumi@unishams.edu.my

\section{References}

Schöbel, S., Schäfer, J., Hausladen, G. (2021). Research through Design under Systematic Quality Criteria: Methodology and Teaching Research. Article in Dimensions, published May 2021. Dimensions of Architectural Knowledge, 202101https://doi $>$ org/10 14361/dak-2021-0113.

Hassan, N. R., Leslie, P., Willcocks. (2021). Introduction: Why Theory? (Mis)Understanding the Context and Rationale. Advancing Information Systems Theories. 2021: 1-52. Published online 2021 Mar 22. DOI: 10.1007/978-3-030-64884-8_1. PMCID: PMC7982084.

Blau, P. J. (2019). An editor's perspective on the quality and content of wear research manuscripts. Volumes 426-427, Part B, 30 April 2019, Pages 1384-1390.

Kibert, C. J., Thiele, L., Peterson, A., Monroe, M. (2012). The Ethics of Sustainability. https://www.cce.ufl.edu/wpcontent/uploads/2012/08/Ethics\%20of\%20Sustainability. 20Textbook.pdf

Stephen, R. C. (1990). The 7 Habits of Highly Effective People. 30th Anniversary Edition. 